C. Resource materials for teaching library skills and for learning bibliographic instruction methods should be collected, critically evaluated and made available on a selective basis.

1. Materials for use in teaching librarians how to do bibliographic instruction (such as textbooks, course outlines, etc.) should be published.

2. A collection of model exercises and other teaching materials should be maintained.

3. A means should be devised by which mate-

rials collected and/or published are evaluated and those evaluations shared with librarians utilizing the materials.

D. An ongoing review should be conducted of the research literature within library/information science and in other academic disciplines having implications for bibliographic instruction (e.g., in scholarly communication, economics of publishing, learning theory). This information should be disseminated to instruction practitioners.

\title{
ACRL Candidates, 1982 Elections
}

The listing for each of the following candidates includes the title, institution, and institutional address.

\section{Vice-Phesident/President-Elect}

Joyce Ball, University Librarian, California State University-Sacramento, 2000 Jed Smith Drive, Sacramento, CA 95819; David H. Stam, The Andrew W. Mellon Director of The Research Libraries, The New York Public Library, 5th Avenue \& 42nd Street, New York, NY 10018.

\section{BOARD OF DiRECTORS}

ACRL Representative to ALA Council: Millicent D. Abell, University Librarian, Central University Library C-075-G, University of California, San Diego, La Jolla, CA 92093; William J. Studer, Director of Libraries, The Ohio State University Libraries, 1858 Neil Avenue Mall, Columbus, OH 43210.

ULS Director-at-Large (1982-1986): Charles B. Lowry, Director of Libraries, University of South Alabama, Mobile, AL 36688; Jean A. Major, Director, University Libraries, Northern Illinois University, Dekalb, IL 60115.

\section{ANTHRopology \& SOCIOLOGY SECTION (ANSS)}

Vice-Chair/Chair-Elect: Jean Shaw Adelman, Librarian, The University Museum, University of Pennsylvania, Philadelphia, PA 19104; Patricia Wand Silvernail, Head, Access Services, Humanities \& History Division, Columbia University Libraries, 535 West 114th Street, New York, NY 10027.

Member-at-Large (two-year term): Chris D. Ferguson, Social Sciences Bibliographer, The University Library, University of CaliforniaIrvine, Irvine, CA 92713; Kathleen Gunning, Head of Reference/Information Services and Collection Development, University Libraries, Central Campus, University of Houston, Houston, TX 77004.

\section{ASIAN AND AFRICAN SECTION (AAS)}

Vice-Chair/Chair-Elect: Tze-chung Li, Professor, Rosary College, Graduate School of Library Science, 7900 West Division, River Forest, IL 60305; Frank M. McGowan, Director, Acquisitions and Overseas Operations, Library of Congress, Washington, D.C. 20540.

Secretary (three-year term): Pauline Tina Lesnik, South Asian Bibliographer, Room 304, International Affairs Building, Columbia University, New York, NY 10027; Ravindra N. Sharma, Head Librarian, Pennsylvania State University, Beaver Campus Library, Monaca, PA 15061.

Member-at-Large (two-year term): Mohammed M. Aman, Dean, School of Library Science, University of Wisconsin-Milwaukee, Milwaukee, WI 53201; David L. Easterbrook, African Studies Area Specialist, Indiana University Libraries, E660 Main Library, Bloomington, IN 47405.

\section{Bibliographic InSTRUCTION SECTION (BIS)}

Vice-Chair/Chair-Elect: Carolyn Dusenbury, Head of Reference Service, 153 University Library, Arizona State University, Tempe, Arizona 85281; Maureen Pastine, Library Director, Library, San Jose State University, San Jose, CA 95192.

Secretary (one-year term): Cerise ObermanSoroka, Head, Reference Department, College of Charleston Library, College of Charleston, Charleston, SC 29401; Richard Hume Werking, Collection Development Librarian, Trinity University, San Antonio, TX 78284.

Member-at-Large (one-year term): Mignon Adams, Coordinator of Information Services, Penfield Library, SUNY/Oswego, Oswego, NY 13126; Ross Atkinson, Humanities Bibliographer, Collection Management Division, Northwestern University Library, Evanston, IL 60201.

Member-at-Large (two-year term): Stephen Lehmann, Humanities Librarian, Love Library, 
University of Nebraska-Lincoln, Lincoln, NE 68588; William Miller, Acting Head, Reference Department, Michigan State University Libraries, East Lansing, MI 48824.

\section{College Libraries Section (CLS)}

Vice-Chair/Chair-Elect: B. Anne Commerton, Director of Libraries/Coordinator of Instructional Services, Pennfield Library, State University of New York, Oswego, NY 13126; Patricia G. Oyler, Associate Professor, Simmons College, Graduate School of Library \& Information Science, 300 The Fenway, Boston, MA 02II5.

Secretary (one-year term): Mary Heing Beilby, Collection Development Librarian, Memorial Library, P.O. Box 2000, Cortland, NY 13045; Elena Ester Cevallos, Reference/Instructional Librarian, Hofstra University Library, Reference Department, Hempstead, NY 11550.

\section{COMMUNITY aNd JUNiOR COLLEGE LibraRiEs SECTION (CJCLS)}

Vice-Chair/Chair-Elect: Ambrose Easterly, Director, Library Services, Harper College Library, Algonquin \& Roselle Roads, Palatine, IL 60067; Mary Sue Ferrell, Chairperson, Learning Resources, Western Nevada Community College, 2201 West Nye Lane, Carson City, NV 89701.

Secretary (one-year term): Peggy Mills, Director, Learning Resource Center, \# I College
Drive, Garland County Community College, Hot Springs, AR 71901; Anne J. Trammell, Director, Learning Resources, North Harris County College, 2700 W. W. Thorne Drive, Houston, TX 77037 .

\section{EuUCation and Behaliorial SCIEnCES SECTION (EBSS)}

Vice-Chair/Chair-Elect: Betty P. Cleaver, Director, Edgar Dale Media Center, Ramseyer Hall, $29 \mathrm{~W}$. Woodruff Avenue, The Ohio State University, Columbus, $\mathrm{OH} 43210$; Virginia $\mathrm{H}$. Parr, Assistant University Librarian for Public Services (Acting), The Library, University of Oregon, Eugene, OR 97403.

\section{Rare BoOks and Manuscripts Section (RBMS)}

Vice-Chair/Chair-Elect: Ellen S, Dunlap, Research Librarian, Humanities Research Center, The University of Texas at Austin, Box 7219, Austin, TX 78712, Stephen Ferguson, Curator of Rare Books, Princeton University Library, Princeton University, Princeton, NJ 08544.

Member-at-Large (three-year term): John R.T. Ettlinger, Professor, School of Library Service, Dalhousie University, Halifax, Nova Scotia, Canada, B3H-4H8; Peter M. VanWingen, Head Reference and Reader Services Section, Rare Book \& Special Collections Division, Library of Congress, Washington, DC 20540.

\section{If You've Got A Problem}

\section{We're Just A (Free) Phone Call Away!}

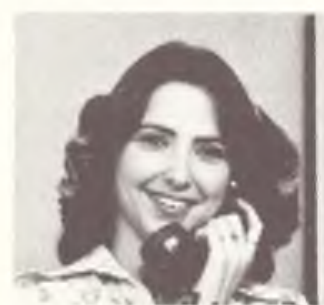

Linda Market

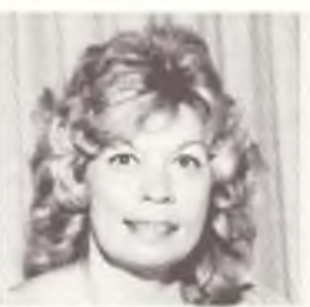

Carol Lehmkuhl

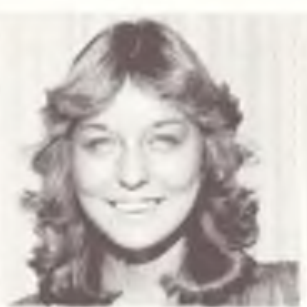

Pam Rodgers

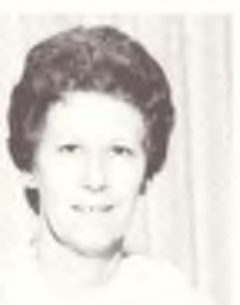

Pat Hamil

Linda and Carol, Pam and Pat are Midwest Library Service's Personal Customer Service Representatives who are specially Irained to solve any book ordering problem your library may encounter. They are thoroughly knowledgeable in all facets of the library jobber business, and if you are ever in need of their services, you can reach them by using our TOLL-FREE WATS Line, 1-800-325-8833 (Missouri customers please call COLLECT: 0-314-739-3100) for help in solving any problem. Your

"20 Years of Service To College and University Libraries"

MIDWEST LIBRARY SERVICE

11443 St. Charles Rock Road

BRIDGETON, Mo. 63044 Customer Service Representative will follow the problem through to a satisfactory conclusion - without delay. Remember Linda and Carol, Pam and Pat are "working" for you and your library. It's all part of Midwest Library Service's tradition of excellence. 
SCIENCE AND TEChNology SECtion (STS)

Vice-Chair/Chair-Elect: John William Beecher, Librarian, The Agriculture Library, University of Illinois, 226 Mumford Hall, 1301 W. Gregory, Urbana, IL 61801; Dolores B. Owen, Head, Government Publications Division, University of Southwestern Louisiana Library, USL Box 40199, Lafayette, LA 70504.

Secretary (one-year term): Alan R. Benefeld, Coordinator, Physical Sciences and Technology Libraries, University of California, Los Angeles, 8251 Boelter Hall, Los Angeles, CA 90024; Frederick B. Getze, Assistant Librarian, Agriculture Library, 002 Agricultural Hall, University of Delaware, Newark, DE 19711.

\section{Slavic and East European Section (SEES)}

Vice-Chair/Chair-Elect: G. Koolemans Beynen, Slavic Bibliographer, Ohio State University Libraries, 1858 Neil Avenue, Columbus, OH 43210; Howard W. Robertson, University of Oregon, Eugene, OR 97402.

Member-at-Large (one-year term): Maria Cap, Library Assistant II, University of California, Serials Department, Main Library, Berkeley, CA 94720; Eleanor R. Payne, Collection Development Department, Library, University of California, Davis, CA 95616; Harold M. Leich, Slavic Acquisitions Librarian, Associate Professor of Library Administration, 225 Library, 1408 West Gregory Drive, Urbana, IL 61801.

\section{UNIVERSITY LIBRARIES SECTION (ULS)}

Vice-Chair/Chair-Elect: Peter D. Haikalis, Head, Reference Services, J. Paul Leonard Library, San Francisco State University, $1630 \mathrm{Hol}$ loway, San Francisco, CA 94132; Jane Ross Moore, Professor and Chief Librarian, The Graduate School \& University Center, City University of New York, 33 West 42nd Street, New York, NY 10036.

Secretary (three-year term): Diane C. Parker, Head of Reference, Lockwood Memorial Library, State University of New York/Buffalo, Amherst, NY 14260; Thomas Shaughnessy, Assistant Director Public Services and Collection Development, University of Houston Libraries, Houston, TX 77004 .

\section{Western European Specialists SECTION (WESS)}

Vice-Chair/Chair-Elect: Anthony M. Angiletta, Bibliographer for the Social Sciences, Yale University Library, Box 1603A, Yale Station, New Haven, CT 06515; Joan F. Higbee, Librarian, Processing Services Department, Library of Congress, Wahington, DC 20540.

Secretary (one-year term): Charles A. D Aniello, History Librarian, Lockwood Memorial Library, SUNY/Buffalo, Amherst, NY 14260; Barbara Halporn, Librarian for Philosophy, Classics, History of Science, Psychology, E1060 Main Library, Indiana University, Bloomington, IN 47405 .

\section{Bring in a Friend}

\section{Dear ACRL, Member:}

The ACRL Board recently proposed that each ACRL member bring in at least one new member to the Association.

The form below is designed for your convenience in listing the name and address of one or more librarians vou know who have an interest in academic or research libraries but who are not ACRL members. Your help in completing this form will assist the Association in contacting persons who can benefit from what ACRL has to offer. As a result, ACRL can continue to serve a growing organization and can become an even stronger influence in academic libraries.

ACRL appreciates your thoughtfulness.

Suggested Name

Street Address

City/State/Zip

Suggested Name

Street Address

City/State/Zip

Name of ACRL member (optional)

Please return to: ACRL, 50 Huron Street, Chicsugo, IL 60611. 
Member-at-Large (one-year term): Anna $\mathrm{H}$. Perrault, Humanities Bibliographer, Louisiana State University Library, Baton Rouge, LA 70803; Richard Bruce Warr, Humanities/History

\section{Hal Espo \\ ACRL Deputy Executive Director}

Editor s Note: Written in response to membership requests, this column features news from ACRL headquarters and discusses features of the office's operations.

We have all had similar experiences. One finds oneself at a party and someone asks what you do for a living. In the past I have easily replied that I was a librarian, and though most people conjure up the stereotypical images of librarianship, at least they knew something about what I did at a reference desk or occasionally in classroom instruction. I am still a librarian by training of course, yet what I do as the deput executive director of a national library association has

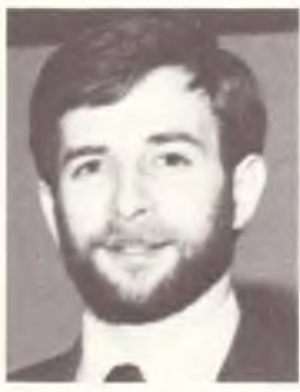

Hal Espo very little in common with what most librarians do and how they were urained in library school. I have discovered that not only do my friends not know what I do on a daily basis, but more importantly many if not most of the ACRL membership does not know what role I play within ACRL. With the opportunity to tell my story, I hope the membership will have a greater appreciation for the size, complexity and scope of the Association.

Since I arrived at ACRL in May, 1978, the Association has grown in responsibilities, programs, budget, and staff. The position of deputy executive director is of a managerial nature in assisting the direction of the headquarters office. Perhaps the best way to describe some of what it is that I do each day is to review my programmatic and administrative responsibilities and to briefly outline what these entail.

1) Support of ACRL committees, sections, chapters, discussion groups, editorial boards, and the Board of Directors. A major responsibility of any administrative position is to make certain that the structure of the organization is maintained sufficiently so that the people who are re-
Bibliographer, Alexander Library, Rutgers - The State University, College Avenue, New Brunswick, NJ 08903.

\section{The View from HQ}

sponsible for programs will be able to function adequately. In order to provide proper support to various ACRL units, we have developed a monthly calendar file. Through the approximately 150 mailings in the file the headquarters office keeps in touch with various unit chairs about ACRL's seemingly endless organizational detail. To further explain, listed below is the description of what is listed in a single month (May) of the file:

1) reports which have been submitted to headquarters by section and committee chairs are prepared for distribution at annual conference;

2) ACRL Guide to Procedures and Policies is updated and distributed to all officers and ACRL unit chairs;

3) an announcement of the recipient of the ACRL Academic or Research Librarian of the Year Award is prepared for C $b R L$ News and distributed to the national library news media;

4) a mailing is sent to section and division election candidates informing them of the election schedule and their responsibilities should they be victorious;

5) thank you letters are sent to all ACRL committee members whose terms have expired following annual conference;

6) all ACRL units are notified of the budget and board orientation meetings at annual conference to assist them in becoming accustomed to how ACRL operates;

7) notice of the annual conference board meeting is sent to all ACRL units with information on how to place items on the board agenda;

8) annual conference board agenda and support materials are sent to board members and section chairs;

9) the Speakers Bureau is prepared and distributed to chapters;

10) file folders are prepared for the upcoming program year (250 files);

11) midwinter board meetings are scheduled by the ACRL President;

12) signs for annual conference program and board meetings are prepared;

13) information on the spring activities of ACRL chapters is solicited;

14) discussion group chairs are reminded to submit incoming officers' names for inclusion in next year's ALA Handbook of Organization;

15) next year's ACRL Academic or Research $\mathrm{Li}$ brarian of the Year nomination form is prepared 